\title{
МАТЕРИАЛЫ К ФАУНЕ СТАФИЛИНИД (COLEOPTЕRA: STAPHYLINIDAE) ТУНДР КАМЧАТКИ (ПодсемеЙства OMALIINAE, PROTEININAE, PSELAPHINAE, TACHYPORINAE И OXYTELINAE)
}

\author{
Рябухин А. С. \\ Институт биологических проблем Севера ДВО РАН, г. Магадан \\ E-mail: asr@ibpn.ru
}

\begin{abstract}
Представлены результаты обобщения литературных данных и обработки материала, собранного в различных районах Камчатки. Для фауны тундр Камчатки выявлено 27 видов стафилинид из 16 родов, относящихся к подсемействам Omaliinae, Proteininae, Pselaphinae, Tachyporinae и Oxytelinae. Из них один таксон идентифицирован только до подсемейства (Pselaphinae gen. sp.). Три вида из родов Bryophacis Reitter, 1909, Mycetoporus Mannerheim, 1830 и Tachyporus Gravenhorst, 1802 из подсемейства Tachyporinae пока не имеют точной видовой идентификации. Большинство видов стафилинид тундр Камчатки широко распространены в Северной Палеарктике и за ее пределами. Составлен аннотированный список видов. Проиллюстрированы пункты сборов.
\end{abstract}

Ключевые слова: стафилиниды, Staphylinidae, фауна, тундры, Камчатка.

DOI: $10.34078 / 1814-0998-2020-2-59-68$

В литературе отсутствуют какие-либо сведения о фауне стафилинид тундр Камчатки, кроме кратких упоминаний в статье Л. Е. Лобковой, В. Б. Семенова (2012). В предлагаемой работе представлены результаты обработки материалов по подсемействам Omaliinae, Proteininae, Pselaphinae, Tachyporinae и Oxytelinae, собранных в тундрах Камчатки в 1989 и 2004-2013 гг.

Для горных тундр характерно почти полное отсутствие стафилинид. В окрестностях пос. Эсco, в гольцовом поясе, в травяно-кустарничковых тундрах обнаружены лишь 4 вида из 3 подсемейств: Omaliinae - Acidota quadrata (Zetterstedt, 1838) и Arpedium brachypterum (Gravenhorst, 1802), Staphylininae - Quedius cf. mesomelinus mesomelinus (Marsham, 1802) и Tachyporinae Tachyporus sp.

Л. Е. Лобкова, В. Б. Семенов (2012: 100) отмечают в горных кустарничковых тундрах Кроноцкого заповедника также 4 вида: Acidota crenata (подсем. Omaliinae), Tachinus elongatus (Tachyporinae), Philonthus ebeninus и Quedius kamchaticus (Staphylininae).

Подавляющее большинство материала собрано в низинных тундрах, которые, как правило, в разной степени и сочетаниях закустарены ивами, ольхой, березой Миддендорфа, изредка - кедровым стлаником. Кустарнички представлены ива-

(C) Рябухин А. С., 2020 ми, карликовой березкой, багульником, шикшей, голубикой, брусникой, реже - морошкой, часто в различных комбинациях. Травянистая растительность выражена весьма неравномерно - от крайне разреженного разнотравья до сплошных, часто закочкаренных, злаковых, осоковых или осоковопушицевых формаций. Напочвенный покров составляют различные виды мхов и лишайников.

\section{МАТЕРИАЛ И МЕТОДЫ}

При сборе материала применялись следующие методы: ручная разборка или просеивание на сифтере почвенной подстилки и других субстратов; сбор эксгаустером с открытых поверхностей и в различных укрытиях; почвенные ловушки (пластиковые стаканы объемом 0.25 л, без фиксатора), выемку пойманного материала из которых выполняли ежедневно. В стационарных условиях использовали фото- и термоэклекторы и светоловушки. При благоприятных погодных условиях осуществляли лов сачком при вечернем лете на фоне неба. Также проводилось обкашивание сачком кустарниковой и травянистой растительности. Собранный материал замаривали хлороформом, сортировали по таксономическим группам и помещали на ватные матрасики или в пробирки с 70\%-ным этиловым спиртом. Дальнейшую его обработку осуществляли в лаборатории. Все пункты сборов отмечены на рисунке. 


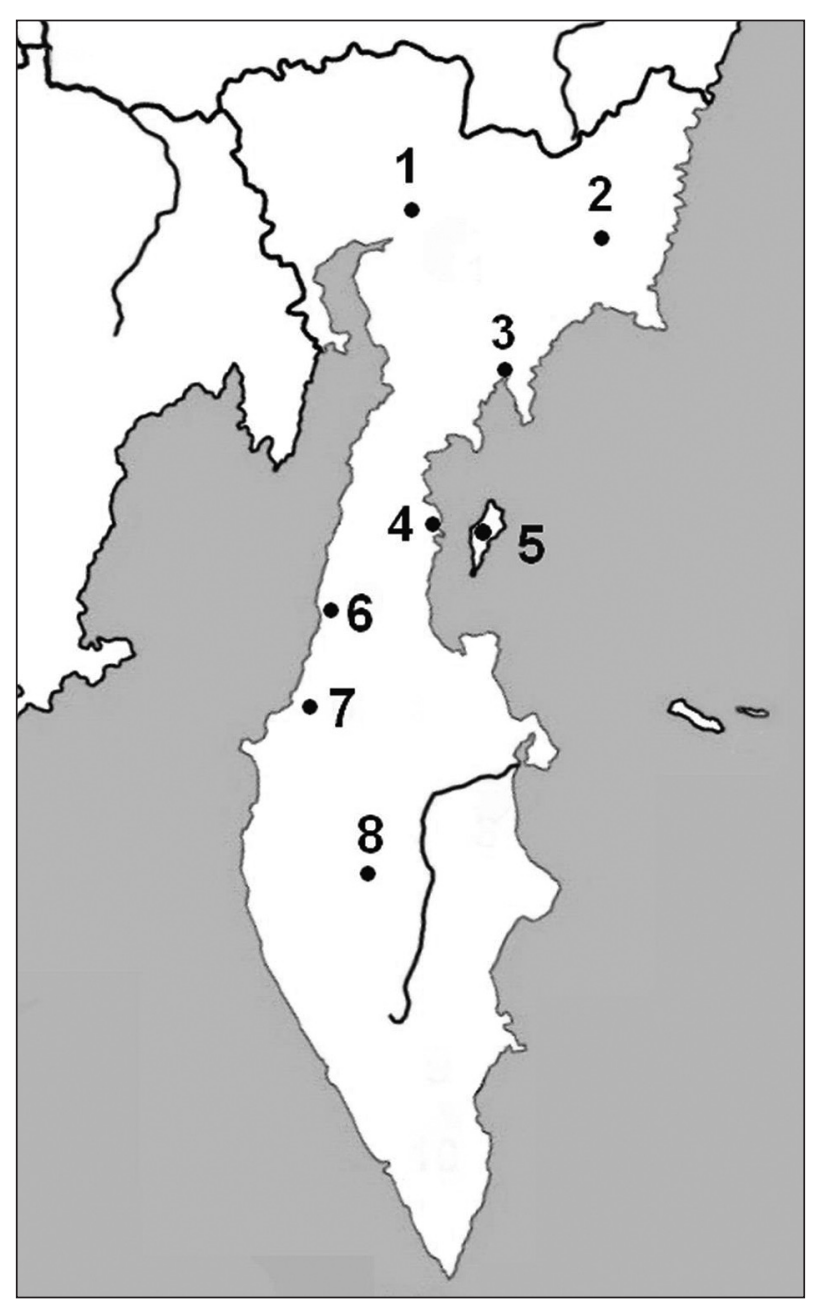

Пункты сборов на территории Камчатки: 1 пос. Каменское; 2 - пос. Ачайваям; 3 - пос. Тиличики; 4 - пос. Оссора; 5 - о. Карагинский; 6 - пос. Палана; 7 - пос. Тигиль; 8 - пос. Эссо

Collecting localities on the territory of Kamchatka: 1 - settlement of Kamenskoye; 2 - settlement of Achayvayam; 3 - settlement of Tilichiki; 4 - settlement of Ossora; 5 - Karaginskiy Island; 6 - settlement of Palana; 7 - settlement of Tigil'; 8 - settlement of Esso

Места хранения материала: Зоологический институт РАН (Санкт-Петербург), Институт биологических проблем Севера ДВО РАН (Магадан).

\section{РЕЗУЛЬТАТЫ И ОБСУЖДЕНИЕ}

Всего было выявлено 27 видов стафилинид из 16 родов, относящихся к подсемействам Omaliinae, Proteininae, Pselaphinae, Tachyporinae и Oxytelinae. Из них один таксон идентифицирован только до подсемейства (Pselaphinae gen. sp.). Три вида (Bryophacis sp., Mycetoporus sp. и Tachyporus sp.) из подсемейства Tachyporinae пока не имеют точной видовой идентификации. Объем собранного материала в количественном выражении составляет около 580 экз.

В приводимом ниже аннотированном списке видов учтены последние номенклатурные изме- нения и данные по распространению (Herman, 2001; Schülke, Smetana, 2015; Shavrin, 2016). Внутри подсемейств таксоны расположены в алфавитном порядке. После видового названия указаны: название ареала с учетом региональной и зональной составляющих по классификации К. Б. Городкова (1984); общее распространение; субрегионы Северо-Востока Азии, где вид известен; биотопическая приуроченность; информация о материале.

Часто встречающийся в тексте термин «старика» означает старую, прошлогоднюю траву, часто сухую сверху и влажную, преющую внизу.

\section{Семейство Staphylinidae Latreille, 1802}

\section{Подсемейство Omaliinae MacLeay, 1825}

Acidota crenata crenata (Fabricius, 1793). Голарктический температный вид. Широко распространен в Европе. В Азии известен из Ирана, Турции, Монголии и южной Кореи. Интродуцирован в Канаду и США. В России встречается в европейской части, Сибири и на Дальнем Востоке (Herman, 2001: 214 (как A. crenata); Schülke, Smetana, 2015: 304). Подвид A. c. japonica Watanabe, 1990 обитает в Японии (Schülke, Smetana, 2015: 305). На Северо-Востоке Азии ранее отмечался (как A. crenata) в Магаданской области (Ryabukhin, 1999: 27) и на Камчатке (Bernhauer, 1925: 2).

Обитает в почвенной подстилке лесов и кустарников, в напочвенном покрове тундр. Л. Е. Лобкова, В. Б. Семенов (2012: 100) отмечают нахождение этого вида в горных кустарничковых тундрах Кроноцкого заповедника.

Материал. Карагинский $\mathrm{p}-\mathrm{H}$, окрестности пос. Оссора, 28.07.2008. Низинная кустарничково-сфагновая тундра у озера. В напочвенном покрове. - 1 экз. А. С. Рябухин.

Acidota quadrata (Zetterstedt, 1838). Палеарктический бореальный вид. Распространен в северной и центральной Европе и Азии (Монголия, Япония), в том числе в северных районах европейской части России, в Сибири и на Дальнем Востоке (Schülke, Smetana, 2015: 305). Помимо этого, L. H. Herman (2001: 218) указывает на его распространение также в Канаде и США, однако M. Schülke, A. Smetana (2015: 305) не подтверждают эти данные. На Северо-Востоке Азии найден в Магаданской области, на Чукотке и Камчатке (Ryabukhin, 1999: 28).

Обитает в напочвенном покрове тундр, в почвенной подстилке лесов, прирусловых зарослей ивы и ольхи, по берегам водоемов среди растительного мусора, прелой травы.

Материал. Быстринский р-н, окрестности пос. Эссо, 16.06.1989. Горное плато, гольцовый пояс, травяно-мохово-кустарничковая тундра. В толще напочвенного покрова. - 3 экз. А. С. Рябухин. 
Карагинский p-н, о. Карагинский, устье p. Гнумваям. 14-27.07.2008. Морская терраса. Кустарничковая тундра (березки, голубика, вороника, морошка) с кедровым стлаником. - 4 экз. О. А. Хрулева.

Олюторский р-н, окрестности пос. Тиличики. 09.07.2012. Низинная кустарничковая тундра, закустаренная ольхой, березой Миддендорфа. В напочвенном покрове. - 1 экз. А. С. Рябухин. Окрестности пос. Ачайваям. 10.07.2013. Низинная кустарничково-моховая тундра. Осоковые кочки, бугры, подушки мхов. Во мху. - 1 экз. А. С. Рябухин.

Arpedium brachypterum (Gravenhorst, 1802). Голарктический арктобореальный вид. На юге ареала встречается в горах. Распространен в Европе, Азии (Монголия) и Северной Америке (Канада и США). В России обитает в северных и центральных районах европейской части, в Сибири и на Дальнем Востоке (Herman, 2001: 284 (как Eucnecosum brachypterum); Schülke, Smetana, 2015: 309). На территории Северо-Востока Азии распространен повсеместно (Ryabukhin, 1999: 25 (как Eucnecosum brachypterum).

Обитает в напочвенном покрове тундр, в почвенной подстилке лесов и кустарников, по берегам водоемов среди выбросов, гниющей травы, во мху. J. М. Campbell (1984: 495) указывает на нахождение этого вида в наземных гнездах птиц, норах грызунов.

Один из фоновых видов для зон тундры и северной тайги.

Arpedium brunnescens J. Sahlberg, 1871. Голарктический арктобореальный вид. На юге ареала встречается в горах. Распространен в северной Европе и Северной Америке (Канада и США). В России обитает в северных районах европейской части и в Сибири (Herman, 2001: 286 (как Eucnecosum brunnescens); Schülke, Smetana, 2015: 310). На территории Северо-Востока Азии распространен повсеместно (Ryabukhin, 1999: 27 (как Eucnecosum brunnescens).

Вид характерен для зон тундры и северной тайги. Обитает вместе с предыдущим видом.

Arpedium tenue (LeConte, 1863). Голарктический арктобореальный вид. На юге ареала встречается в горах. Распространен в Европе и Северной Америке (Канада и США). В России обитает в северных районах европейской части, в Сибири и на Дальнем Востоке (Herman, 2001: 287 (как Eucnecosum tenue); Schülke, Smetana, 2015: 310). На территории Северо-Востока Азии распространен повсеместно (Ryabukhin, 1999: 26 (как Eucnecosum brunnescens).

Один из фоновых видов для зон тундры и северной тайги. Обитает вместе с предыдущим видом.

Boreaphilus henningianus C. R. Sahlberg, 1832. Голарктический арктобореальный вид. Рас- пространен в северной Европе, Азии (Монголия) и Северной Америке (Канада и США). В России обитает в северных районах европейской части, в Сибири и на Дальнем Востоке (Herman, 2001: 384; Schülke, Smetana, 2015: 328). Для СевероВостока Азии ранее приводился для Магаданской области и Чукотки (Ryabukhin, 1999: 34).

Обитает во влажной подстилке прибрежных зарослей ивы, ольхи; среди гниющей травяной растительности, в напочвенном покрове тундр, в выбросах по берегам водоемов, на болотах. J. M. Campbell (1978:64) приводит нахождение этого вида в гниющих грибах рода Boletus, а также под подсохшим конским пометом.

Материал. Тигильский p-н, окрестности пос. Тигиль. 27.07.2010. Надпойменная терраса р. Тигиль. Разнотравно-осоковая низинная влажная тундра, закустаренная редкими кустами ивы, ольхи и березы. Довольно много мхов. Низкие осоковые и злаковые кочки. Между ними иногда старика. В напочвенном покрове. - 1 экз. А. С. Рябухин.

Пенжинский р-н, окрестности пос. Каменское. 16-18.07.2011. Низинная кустарничковая тундра. Влажный участок, закустаренный ольхой, ивой, березой Миддендорфа. Небольшие, почти заросшие болотца с осокой и пышными мхами. Oсоковые кочки и бугры. В подстилке. -2 экз. А. С. Рябухин. 20.07.2011. Там же. «Ленточное» пышное злаковое высокотравье по руслу практически пересохшего ручейка. Мощная многолетняя старика, от сухой сверху до мокрой, гниющей внизу. В ее среднем и нижнем слоях. - 9 экз. А. С. Рябухин. 31.07.2011. Там же. Западный шлейф сопки. Низинная кустарничковая тундра. Осоковые кочки, злаки, довольно много мхов. Между кочками - старика, листовой опад от кустарников. На фоне тундры довольно редкая поросль ольхи и ивы. В напочвенном покрове, во мху. -7 экз. А. С. Рябухин.

Holoboreaphilus nordenskioldi (Mäklin, 1878). Голарктический арктобореальный вид. Распространен в северных районах европейской части, в Сибири и на Дальнем Востоке России, в Канаде и США (Herman, 2001: 404; Schülke, Smetana, 2015: 331). На Северо-Востоке Азии отмечен в Магаданской области и на Чукотке (Ryabukhin, 1999: 34 (как H. nordenskioeldi).

Обитает в почвенной подстилке прирусловых зарослей ивы, ольхи; в речных выбросах, во мху по берегам водоемов, на болотах, в напочвенном покрове тундр.

Материал. Пенжинский $\mathrm{p}-\mathrm{H}$, окрестности пос. Каменское. 31.07.2011. Западный шлейф сопки. Низинная кустарничковая тундра. Осоковые кочки, злаки, довольно много мхов. Между кочками - старика, листовой опад от кустарничков. На фоне тундры довольно редкая поросль 
ольхи и ивы. В напочвенном покрове. - 1 экз. А. С. Рябухин.

Olophrum boreale (Paykull, 1792). Голарктический арктобореальный вид. Распространен в северной Европе, Канаде и США. В России обитает в северных районах европейской части, в Сибири и на Дальнем Востоке (Herman, 2001: 342; Schülke, Smetana, 2015: 322). На Северо-Востоке Азии отмечен в Магаданской области, на Чукотке и Камчатке (Ryabukhin, 1999: 23). Характерен для зон тундры, лесотундры и северной тайги. На юге ареала встречается в горах.

Обитает в напочвенном покрове тундр, в пойменных, особенно в прирусловых, биотопах: в почвенной подстилке, речных наносах, во мху, под камнями.

Материал. Пенжинский $\mathrm{p}-\mathrm{H}$, окрестности пос. Каменское. 20.07.2011. Низинная моховокустарничковая тундра. «Ленточное» пышное злаковое высокотравье по руслу практически пересохшего ручейка. Мощная многолетняя старика, от сухой сверху до мокрой, гниющей внизу. В ее среднем и нижнем слоях. -2 экз. А. С. Рябухин.

Olophrum consimile (Gyllenhal, 1810). Голарктический арктобореальный вид. Распространен в Европе, Канаде и США. В России обитает в северных и центральных районах европейской части, в Сибири и на Дальнем Востоке (Herman, 2001: 343; Schülke, Smetana, 2015: 322). Нa Северо-Востоке Азии известен из Магаданской области и с Камчатки (Ryabukhin, 1999: 22).

Обитает в почвенной подстилке лесов, во мху, в выбросах по берегам водоемов.

Материал. Карагинский p-н, окрестности пос. Оссора. 11.07.2008. Влажная низинная кустарничково-сфагновая тундра у озера. Кустарничковый покров местами очень густой. Кроме сфагнума много и других мхов. Во мху. -1 экз. А. С. Рябухин.

Тигильский $\mathrm{p}-\mathrm{H}$, окрестности пос. Палана. 20.07.2009. Низинная кустарничково-травяномоховая крупнобугристая тундра. Местами, на возвышенных участках, - подушки лишайников. В напочвенном покрове. -1 экз. А. С. Рябухин. Окрестности пос. Тигиль. 25-28.07.2010. Надпойменная терраса $p$. Тигиль. Влажная разнотравноосоковая низинная тундра, закустаренная редкими кустами ивы, ольхи и березы. Низкие осоковые и злаковые кочки. Довольно много мхов, иногда - старики. Во влажной старике между кочками, во мху. - 13 экз. А. С. Рябухин.

Пенжинский p-н, окрестности пос. Каменское. 16.07.2011. Низинная кустарничковая тундра. Влажный участок, закустаренный ольхой, ивой, березой Миддендорфа. Небольшие, почти заросшие болотца с осокой и пышными мхами по берегам. Осоковые кочки, бугры. Во влажной старике между кочками. - 1 экз. А. С. Рябухин.
Olophrum latum Mäklin, 1853. Сибирсконеарктический арктобореальный вид. Распространен в Монголии, Канаде и США. В России обитает в Сибири и на Дальнем Востоке (Herman, 2001: 349; Schülke, Smetana, 2015: 323). На Северо-Востоке Азии известен из Магаданской области, с Чукотки и Камчатки (Ryabukhin, 1999: 24). Характерен для зоны тундр, лесотундр и северной тайги. На юге ареала встречается в горах.

Обитает в почвенной подстилке лесов и кустарников, в напочвенном покрове тундр, среди выбросов по берегам водоемов, во мху, под камнями. Изредка - под трупами мелких животных (Campbell, 1983: 615).

Материал. Пенжинский $\mathrm{p}-\mathrm{H}$, окрестности пос. Каменское. 20.07.2011. Низинная моховокустарничковая тундра. «Ленточное» пышное злаковое высокотравье по руслу практически пересохшего ручейка. Мощная многолетняя старика. От сухой сверху до мокрой, гниющей внизу. В ее среднем и нижнем слоях. - 2 экз. А. С. Рябухин.

Olophrum rotundicolle (C. R. Sahlberg, 1830). Голарктический арктобореальный вид. Распространен в центральной и северной Европе, Канаде и США. В России обитает в северных районах европейской части, в Сибири и на Дальнем Востоке (Herman, 2001: 352; Schülke, Smetana, 2015: 323). На Северо-Востоке Азии известен из Магаданской области, с Чукотки и Камчатки (Ryabukhin, 1999: 23).

Обитает по влажным илистым и илистопесчаным берегам водоемов среди осоки, мха; в прелой траве, листовом опаде, в речных выброcax; изредка - под камнями.

Материал. Пенжинский $\mathrm{p}-\mathrm{H}$, окрестности пос. Каменское. 20.07.2011. Низинная моховокустарничковая тундра. «Ленточное» пышное злаковое высокотравье по руслу практически пересохшего ручейка. Мощная многолетняя старика. От сухой сверху до мокрой, гниющей внизу. В ее среднем и нижнем слоях. - 3 экз. А. С. Рябухин. 21.07.2011. Низинная травяно-моховокустарничковая тундра. Осоковые кочки, бугры. Более влажный участок, закустаренный ольхой, ивой, березой Миддендорфа. Небольшие, почти заросшие болотца с осокой и пышными мхами. 1 экз. А. С. Рябухин.

Карагинский p-н, о. Карагинский. Устье p. Гнумваям. 14-27.07.2008. Морская терраса. Кустарничковая тундра (березки, голубика, вороника, морошка) с кедровым стлаником. - 4 экз. О. А. Хрулева.

Omalium oxyacanthae Gravenhorst, 1806. Голарктический субарктотемператный вид. Имеет обширный ареал, распространен в Европе, Северной Африке (Алжир) и Азии (Турция, Китай 
(пров. Хэйлунцзян)). Интродуцирован в США. В России обитает в Сибири и на Дальнем Востоке (Herman, 2001: 522; Schülke, Smetana, 2015: 347). На Северо-Востоке Азии известен из Магаданской области и с Камчатки (Ryabukhin, 1999: 16).

Обитает во влажной подстилке лесов и кустарников, среди выбросов на илистых берегах водоемов, в грибах, на падали, экскрементах, пищевых отбросах.

Материал. Тигильский $\mathrm{p}-\mathrm{H}$, окрестности пос. Тигиль. 25.07.2010. Надпойменная терраса p. Тигиль. Разнотравно-осоковая влажная низинная тундра, закустаренная редкими кустами ивы, ольхи и березы. Низкие осоковые и злаковые кочки. Довольно много мхов, местами - старики. В напочвенном покрове. -1 экз. А. С. Рябухин.

Pycnoglypta heydeni Eppelsheim, 1886. Сибиро-неарктический арктобореальный вид. В Палеарктике распространен в Сибири и на Дальнем Востоке. В Неарктике известен в США (Аляска) и Канаде (Юкон, Северо-Западные Территории) (Herman, 2001: 580; Schülke, Smetana, 2015: 351). На Северо-Востоке Азии отмечен в Магаданской области, на Чукотке (Ryabukhin, 1999: 15), Камчатке и в северных районах Хабаровского края (Shavrin, 2016: 24).

Обитает в почвенной подстилке пойменных лесов и кустарников; напочвенном покрове тундр; по берегам водоемов среди выбросов, гниющей травы; на болотах.

Материал. Тигильский $\mathrm{p}-\mathrm{H}$, окрестности пос. Тигиль. 25-28.07.2010. Надпойменная терpaca p. Тигиль. Влажная разнотравно-осоковая низинная тундра, закустаренная редкими кустами ивы, ольхи и березы. Низкие осоковые и злаковые кочки. Довольно много мхов, местами старики. В напочвенном покрове. -6 экз. А. С. Рябухин.

Пенжинский p-н, окрестности пос. Каменское. 10-19.07.2011. Низинная кустарничковая тундра, слабо закустаренная ольхой. Единичные кусты березы Миддендорфа, ивы. Небольшие осоковые кочки. Местами куртины мхов. Пересыхающие или уже практически высохшие небольшие болотца. В напочвенном покрове, во мху. - 5 экз. А. С. Рябухин. 20.07.2011. Низинная мохово-кустарничковая тундра. «Ленточное» пышное злаковое высокотравье по руслу практически пересохшего ручейка. Мощная многолетняя старика. От сухой сверху до мокрой, гниющей внизу. В ее среднем и нижнем слоях. -1 экз. А. С. Рябухин. 21.07.2011. Низинная кустарничковая тундра. Осоковые кочки, бугры. Влажный участок, более закустаренный ольхой, ивой, березой Миддендорфа. Небольшие почти заросшие болотца с осокой и пышными мхами. В подстилке. -1 экз. А. С. Рябухин.

\section{Подсемейство Proteininae Erichson, 1839}

Proteinus brachypterus (Fabricius, 1793). Голарктический субарктотемператный вид. Имеет обширный ареал, распространен в Европе, Cеверной Африке, Азии (Казахстан, Турция), США. В России обитает в Сибири (Herman, 2001: 639; Schülke, Smetana, 2015: 356). На Северо-Востоке Азии найден в Магаданской области (Ryabukhin, 1999: 12). баx.

Обитает в сырой почвенной подстилке, гри-

Материал. Пенжинский p-н, окрестности пос. Каменское. 31.07.2011. Западный шлейф сопки. Низинная мохово-кустарничковая тундра. Осоковые кочки, злаки, довольно много мхов. Между кочками - старика, листовой опад. На фоне тундры довольно редкая поросль ольхи и ивы. В подстилке. - 1 экз. А. С. Рябухин.

Подсемейство Pselaphinae Latreille, 1802

\section{Pselaphinae gen. sp.}

Материал. Тигильский p-н, окрестности пос. Тигиль. 25.07.2010. Надпойменная терраса р. Тигиль. Разнотравно-осоковая влажная низинная тундра, закустаренная редкими кустами ивы, ольхи и березы. Низкие осоковые и злаковые кочки. Довольно много мхов, местами - старики. В подстилке, во мху. - 50 экз. А. С. Рябухин. 26-28.07.2010. Там же. Участок с отдельными куртинами карликовой березки и более густыми, но низкими кустами ивы. Довольно много клюквы, мелких вересковых и гречишных. - 108 экз. А. С. Рябухин.

Подсемейство Tachyporinae MacLeay, 1825

Bryophacis rugipennis (Pandelle, 1869). Палеарктический температный вид. Распространен в Европе и Азии (Турция). В России обитает на Дальнем Востоке (Herman, 2001: 702; Schülke, Smetana, 2015: 457). На Северо-Востоке Азии ранее был отмечен для Камчатки (Bernhauer, 1925: 2 (как Bryoporus rugipennis), Магаданской области и Чукотки (Ryabukhin, 1999: 78 (как Bryoporus (Bryophacis) rugipennis).

Обитает в почвенной подстилке лесов и кустарников, в напочвенном покрове тундр.

Материал. Пенжинский $\mathrm{p}-\mathrm{H}$, окрестности пос. Каменское. 19.07.2011. Низинная кустарничковая тундра. Редкие кусты ольхи, ивы, березы Миддендорфа. Осоковые кочки, бугры, подушки мхов. В напочвенном покрове. - 2 экз. А. С. Рябухин. 31.07.2011. Западный шлейф сопки. Низинная кустарничковая тундра. Осоковые кочки, злаки, довольно много мхов. Между кочками - старика, листовой опад. На фоне тундры редкая поросль ольхи, березы Миддендорфа и ивы. В подстилке. -2 экз. А. С. Рябухин.

Олюторский p-н, окрестности пос. Ачайваям. 15.07.2013. Низинная кустарничковая тундра. Влажный участок с буграми и густыми за- 
рослями карликовой березки и ивы. В подстилке. -1 экз. А. С. Рябухин. 29.07.2013. Там же. Верхний слой напочвенного покрова совершенно сухой. Только в локальных понижениях влажные подушки мхов. - 1 экз. А. С. Рябухин.

Bryophacis sp.

Материал. Пенжинский p-н, окрестности пос. Каменское. 15.07.2011. Низинная моховокустарничковая тундра. Редкие кусты ольхи, ивы, березы Миддендорфа. Осоковые кочки, бугры, подушки мхов. В напочвенном покрове. 2 экз. А. С. Рябухин.

Ischnosoma splendidum (Gravenhorst, 1806). Мультирегиональный вид. Имеет обширный ареал, распространен в Европе, Северной Африке, Азии, а также в Северной Америке (Канада, США) и Ориентальной (Индо-Малайской) области. В России встречается в европейской части, Сибири и на Дальнем Востоке (Herman, 2001: 724; Schülke, Smetana, 2015: 460). На Северо-Востоке Азии распространен повсеместно (Ryabukhin, 1999: 77).

Обитает в напочвенном покрове тундр, в почвенной подстилке лесов и кустарников, во мху, в гниющих растительных остатках, под камнями, корягами; изредка - на побережье среди морских выбросов. С. И. Медведев, Е. Ф. Соснина (1973: 823 ) отмечают его присутствие как энтомофага в наземных гнездах мышей.

Материал. Тигильский $\mathrm{p}-\mathrm{H}$, окрестности пос. Палана. 8.08.2009. Низинная кустарничковотравяно-моховая крупнобугристая тундра. Местами, на возвышенных участках - подушки лишайников. В напочвенном покрове. - 2 экз. А. С. Рябухин.

Lordithon thoracicus thoracicus (Fabricius, 1777). Палеарктический полизональный вид. Имеет обширный ареал, распространен в Европе, Северной Африке и Азии. В России встречается в европейской части, Сибири и на Дальнем Востоке. Подвид L. th. luridus (Wollaston, 1864) обитает на Канарских островах (Schülke, Smetana, 2015: 463). Помимо этого, L. H. Herman (2001: 753) приводит его (как L. thoracicus), в том числе для Канады и США, однако M. Schülke, A. Smetana (2015: 463) не подтверждают эти данные. На Северо-Востоке Азии М. Bernhauer (1925: 2) указывает его (как Bolitobius thoracicus) для Камчатки. A. S. Ryabukhin (1999: 79) отмечает его нахождение (как L. (s. str.) thoracicus) в Магаданской области и на Чукотке.

Обитает в трубчатых и, реже, пластинчатых грибах; изредка встречается в трутовиках, растительных остатках, во мху, под корой поваленных трухлявых лиственных деревьев. Один экземпляр был пойман на морском побережье среди влажных водорослей.

Материал. Тигильский р-н, окрестности пос. Тигиль. 26.07.2010. Надпойменная терраса р. Ти- гиль. Разнотравно-осоковая влажная низинная тундра, закустаренная редкими кустами ивы, ольхи и березы. Низкие осоковые и злаковые кочки. Довольно много мхов, иногда - старики. Участок с отдельными куртинами карликовой березы и более густыми, но низкими, кустами ивы. Много клюквы, мелких вересковых и гречишных. В напочвенном покрове. -1 экз. А. С. Рябухин.

Mycetoporus nigrans Mäklin, 1853. Голарктический бореальный вид. Распространен в Европе, Азии (Монголия) и Северной Америке (Канада, США). В России обитает в северных районах европейской части, в Сибири и на Дальнем Востоке (Schülke, Smetana, 2015: 466). L. H. Herman (2001: 789) считал этот вид неарктическим. На Северо-Востоке Азии встречается в Магаданской области, на Чукотке и Камчатке (Ryabukhin, 1999: 76).

Обитает в почвенной подстилке лесов и кустарников, в напочвенном покрове тундр, по берегам ручьев в выбросах, под камнями, во мху.

Материал. Карагинский $\mathrm{p}-\mathrm{H}$, окрестности пос. Оссора. 28.07.2008. Низинная кустарничково-сфагновая тундра у озера. На участках с редкими кустарничками много морошки. В напочвенном покрове, во мху. - 4 экз. А. С. Рябухин.

Тигильский $\mathrm{p}-\mathrm{H}$, окрестности пос. Палана. 20.07.2009. Низинная кустарничково-травяномоховая крупнобугристая тундра. Местами, на возвышенных участках, - подушки лишайников. В напочвенном покрове. -2 экз. А. С. Рябухин. 8-9.08.2009. Там же. - 10 экз. А. С. Рябухин. Окрестности пос. Тигиль. 25.07.2010. Надпойменная терраса р. Тигиль. Разнотравно-осоковая влажная низинная тундра, закустаренная редкими кустами ивы, ольхи и березы. Низкие осоковые и злаковые кочки. Довольно много мхов, местами - старики. В напочвенном покрове. -2 экз. А. С. Рябухин. 26.07.2010. Там же. Участок с отдельными куртинами карликовой березки и более густыми, но низкими кустами ивы. Довольно много клюквы, мелких вересковых и гречишных. - 1 экз. А. С. Рябухин. 27-28.07.2010. Там же. -6 экз. А. С. Рябухин.

Пенжинский p-н, окрестности пос. Каменское. 10.07.2011. Низинная кустарничковая тундра, слабо закустаренная ольхой. Единичные кусты березы Миддендорфа, ивы. Местами куртины мхов. Небольшие осоковые кочки. Пересыхающие или уже практически высохшие небольшие болотца. В напочвенном покрове, во мху. - 6 экз. А. С. Рябухин. 19.07.2011. Там же. -8 экз. А. С. Рябухин. 20.07.2011. Там же. «Ленточное» пышное злаковое высокотравье по руслу практически пересохшего ручейка. Мощная многолетняя старика. От сухой сверху до мокрой, гниющей внизу. В ее среднем и нижнем слоях. - 3 экз. А. С. Рябухин. 31.07.2011. Западный шлейф сопки. Низинная ку- 
старничковая тундра, слабо закустаренная кустами ольхи, ивы, березы Миддендорфа. Осоковые кочки, бугры, злаки, довольно много мхов. Между кочками - старика, листовой опад от кустарников. В подстилке, во мху. - 4 экз. А. С. Рябухин.

Олюторский р-н, окрестности пос. Ачайваям. 14-15.07.2013. Низинная кустарничковая тундра. Более влажный участок с буграми и густыми зарослями карликовой березки, ивы и, местами, голубики. В подстилке. - 4 экз. А. С. Рябухин. 2529.07.2013. Там же. Верхний слой напочвенного покрова совершенно сухой. Только в локальных понижениях влажные подушки мхов. Во мху. 5 экз. А. С. Рябухин.

\section{Mycetoporus sp.}

Материал. Тигильский p-н, окрестности пос. Тигиль. 25.07.2010. Надпойменная терраса р. Тигиль. Разнотравно-осоковая влажная низинная тундра, закустаренная редкими кустами ивы, ольхи и березы. Низкие осоковые и злаковые кочки. Довольно много мхов, местами - старики. В напочвенном покрове. - 1 экз. А. С. Рябухин. 2628.07.2010. Там же. Участок с отдельными куртинами карликовой березки и более густыми, но низкими кустами ивы. Довольно много клюквы, мелких вересковых и гречишных. В подстилке. 7 экз. А. С. Рябухин.

Пенжинский р-н, окрестности пос. Каменское. 15.07.2011. Низинная мохово-кустарничковая тундра. Редкие кусты ольхи, ивы, березы Миддендорфа. Осоковые кочки, бугры, подушки мхов. В напочвенном покрове, во мху. - 2 экз. А. С. Рябухин. 16.07.2011. Там же, но более влажный и сильнее закустаренный участок. Небольшие почти заросшие болотца с осокой и пышными мхами. В подстилке. - 4 экз. А. С. Рябухин.

Tachinus (s. str.) elongatus Gyllenhal, 1810. Голарктический субарктотемператный вид. Имеет обширный ареал, распространен в Европе, Азии, Северной Америке (США, Канада). В России встречается в европейской части, в Сибири и на Дальнем Востоке (Herman, 2001: 939; Schülke, Smetana, 2015: 478). На Северо-Востоке Азии известен из Магаданской области и с Камчатки (Ryabukhin, 1999: 93).

Обитает во влажных биотопах: в сырой лесной подстилке, в гниющих листьях, во мху на болотах, на топких илистых берегах водоемов среди растительного мусора, под камнями; иногда в гниющих грибах; возле снежников. J. М. Саmpbell (1973: 35) указывает на его нахождение в северных частях ареала на морских побережьях среди гниющих водорослей; изредка в навозе и падали. Л. Е. Лобкова, В. Б. Семенов (2012: 100) приводят его для горных кустарничковых тундр Кроноцкого заповедника.

Материал. Карагинский p-н, о. Карагинский, устье р. Гнумваям. 14-27.07.2008. Морская тер- раса. Кустарничковая тундра (березки, голубика, вороника, морошка) с кедровым стлаником. 2 экз. О. А. Хрулева.

Tachyporus (Palporus) nitidulus (Fabricius, 1781). Мультирегиональный вид. Имеет обширный ареал, в Палеарктике широко распространен в Европе и Азии, а также в Северной Африке. Известен из Афротропической и Ориентальной (Индо-Малайской) областей. Интродуцирован в Неарктике и Австралийской областях. В России встречается в европейской части, Сибири и на Дальнем Востоке (Herman, 2001: 1030; Schülke, Smetana, 2015: 484). На Северо-Востоке Азии известен из Магаданской области, с Чукотки и Камчатки (Ryabukhin, 1999: 83).

Обитает преимущественно во влажных биотопах: по берегам рек, озер, болот среди выбросов, во мху, в почвенной подстилке, разлагающихся растительных остатках. С. И. Медведев, Е. Ф. Соснина (1973: 823), С. И. Медведев, В. Е. Скляр (1974: 565) отмечают его нахождение в подземных норах мелких грызунов. М. Н. Hatch (1957: 122) указывает на спорадическое присутствие этого вида в гнездах муравьев рода Formica.

Материал. Карагинский р-н, окрестности пос. Ocсора. 28.07.2008. Низинная кустарничковосфагновая тундра у озера. На участках с редкими кустарничками много морошки. Во мху. - 4 экз. А. С. Рябухин.

Тигильский p-н, окрестности пос. Палана. 20.07.08.2009. Низинная кустарничково-травяномоховая крупнобугристая тундра. Местами, на возвышенных участках, - подушки лишайников. В напочвенном покрове. - 4 экз. А. С. Рябухин. Окрестности пос. Тигиль. 27.07.2010. Надпойменная терраса р. Тигиль. Разнотравно-осоковая влажная низинная тундра, закустаренная редкими кустами ивы, ольхи и березы. Низкие осоковые и злаковые кочки. Довольно много мхов, иногда - старики. В напочвенном покрове. 1 экз. А. С. Рябухин.

Пенжинский р-н, окрестности пос. Каменское. 10.07.2011. Низинная кустарничковая тундра, слабо закустаренная ольхой. Единичные кусты березы Миддендорфа, ивы. Небольшие осоковые кочки. Местами куртины мхов. Пересыхающие или уже практически высохшие небольшие болотца. В подстилке. - 1 экз. А. С. Рябухин. 15.07.2011. Низинная кустарничковая тундра. Редкие кусты ольхи, ивы, березы Миддендорфа. Осоковые кочки, бугры, подушки мхов. В напочвенном покрове. - 2 экз. А. С. Рябухин. 16.07.2011. Там же, но более влажный и закустаренный участок. Небольшие, почти заросшие болотца с осокой и пышными мхами. В подстилке. -6 экз. А. С. Рябухин.

Олюторский р-н, окрестности пос. Тиличики. 25.07.2012. Очень пологий склон приморской 
террасы. Низинная тундра, закустаренная ивой, березой Миддендорфа, местами ольхой. Много мхов. Иногда - куртины лишайников. В напочвенном покрове, во мху. - 3 экз. А. С. Рябухин.

Tachyporus (s. str.) abdominalis (Fabricius, 1781). Голарктический субарктотемператный вид. Широко распространен в Европе. Также обитает в Азии (северо-восточный Китай, Монголия, Япония) и Северной Америке (США, Канада). В России встречается в европейской части, в Сибири и на Дальнем Востоке (Herman, 2001: 1001; Schülke, Smetana, 2015: 485). На СевероВостоке Азии известен в Магаданской области и на Камчатке (Ryabukhin, 1999: 84).

Обитает во влажных биотопах: в подстилке лесов, под камнями, под корой и в толще трухлявой древесины поваленных деревьев, по берегам рек, озер, болот среди выбросов; иногда - в гнилых грибах, на кухонных отбросах.

Материал. Тигильский p-н, окрестности пос. Палана. 8-9.08.2009. Низинная кустарничковотравяно-моховая крупнобугристая тундра. Местами, на возвышенных участках, - подушки лишайников. В напочвенном покрове. -7 экз. А. С. Рябухин.

Пенжинский р-н, окрестности пос. Каменское. 19.07.2011. Низинная кустарничковая тундра. Редкие кусты ольхи, ивы, березы Миддендорфа. Осоковые кочки, бугры, подушки мхов. В напочвенном покрове. - 3 экз. А. С. Рябухин. 21.07.2011. Там же, но более влажный и закустаренный участок. Небольшие почти заросшие болотца с осокой и пышными мхами. В подстилке, во мху. - 4 экз. А. С. Рябухин. 20.07.2011. Низинная кустарничковая тундра. «Ленточное» пышное злаковое высокотравье по руслу практически пересохшего ручейка. Мощная многолетняя старика. От сухой сверху до мокрой, гниющей внизу. В ее среднем и нижнем слоях. -4 экз. А. С. Рябухин.

Олюторский р-н, окрестности пос. Ачайваям. 10.07.2013. Низинная кустарничковая тундра. Осоковые кочки, злаки, довольно много мхов. В напочвенном покрове. -3 экз. А. С. Рябухин. 1415.07.2013. Там же. Более влажный участок с буграми и густыми зарослями карликовой березки и ивы. -5 экз. А. С. Рябухин.

Tachyporus (s. str.) pusillus Gravenhorst, 1806. Палеарктический полизональный вид. Имеет обширный ареал, распространен в Европе, Северной Африке и Азии. В России встречается в европейской части, Сибири и на Дальнем Востоке (Herman, 2001: 1042; Schülke, Smetana, 2015: 488). На Северо-Востоке Азии известен из Магаданской области (Ryabukhin, 1999: 86) и с Камчатки (Bernhauer, 1925: 1 (как T. macropterus).

Обитает в почвенной подстилке лесов и кустарников; на полянах, лугах под различными предметами на почве. С. И. Медведев, Е. Ф. Соснина (1973: 823), С. И. Медведев, В. Е. Скляр (1974: 565) отмечают его нахождение в подземных и, реже, наземных гнездах полевок и мышей.

Материал. Карагинский $\mathrm{p}-\mathrm{H}$, окрестности пос. Оссора. 20.07.2008. Кустарничковая тундра на террасе. Много мхов. Иногда под кустами багульника и голубики подушки сфагнума. В напочвенном покрове. - 2 экз. А. С. Рябухин.

Пенжинский р-н, окрестности пос. Каменское. 31.07.2011. Западный шлейф сопки. На фоне тундры довольно редкая поросль ольхи и ивы. Oсоковые кочки, злаки, довольно много мхов. Между кочками - старика, листовой опад от кустарников. В подстилке. -3 экз. А. С. Рябухин.

Олюторский р-н, окрестности пос. Ачайваям. 25-29.07.2013. Низинная кустарничковая тундра. Много карликовой березки, ивы, голубики. Верхний слой напочвенного покрова совершенно сухой. Только в локальных понижениях относительно влажные подушки мхов. Во мху. -4 экз. А. С. Рябухин.

Tachyporus sp.

Материал. Быстринский p-н, окрестности пос. Эссо. 16.06.1989. Гольцовый пояс. Травяномохово-кустарничковая тундра. В толще напочвенного покрова, под камнями. - 1 экз. А. С. Рябухин.

Подсемейство Oxytelinae Fleming, 1821

Oxytelus assingi Schülke, 2012. Вид описан из Краснодарского края. В настоящее время известен также из Смоленской и Мурманской областей и с Камчатки (Рябухин, Гильденков, 2018: 148).

Материал. Тигильский $\mathrm{p}-\mathrm{H}$. Окрестности пос. Тигиль. 25.07.2010. Надпойменная терраca p. Тигиль. Разнотравно-осоковая влажная низинная тундра, закустаренная редкими кустами ивы, ольхи и березы. Отдельные осоковые и злаковые кочки. Местами много старики, мхов. В напочвенном покрове. -2 экз. А. С. Рябухин.

Пенжинский p-н. Окрестности пос. Каменское. 20.07.2011. Мохово-кустарничковая низинная тундра. Пышное «ленточное» злаковое высокотравье по руслу почти пересохшего ручейка. Мощная многолетняя старика, от сухой сверху до мокрой, гниющей внизу. В ее среднем и нижнем слоях. - 1 экз. А. С. Рябухин.

Работа выполнена при финансовой поддержке ДВО РАН (гранты № 04-3-E-06-018, 05-III-E-0630, 06-IІІ-Д-06-246，08-III-Д-06-058，10-ІІІ-Д-06-020, 12-III-L-06-021, 13-III-L-06-003).

\section{ЛИТЕРАТУРА}

Городков К. Б. Типы ареалов насекомых тундры и лесных зон европейской части СССР // Ареалы насекомых европейской части СССР : атлас. Карты 179221. Л. : Наука, 1984. С. 3-20. 
Лобкова Л. Е., Семенов В. Б. Стафилиниды (Соleoptera, Staphylinidae) Кроноцкого заповедника и сопредельных территорий Камчатки // Тр. Кроноцкого государственного природного биосферного заповедника. П.-Камчатский : Камчатпресс, 2012. Вып. 2. C. 85-102.

Медведев С. И., Скляр В. Е. Жуки (Coleoptera) из гнезд мелких млекопитающих Донецкой области // Энтомологическое обозрение. 1974. Т. 53, № 3. C. $561-571$.

Медведев С. И., Соснина Е. Ф. Жуки (Coleoptera) из гнезд мышевидных грызунов в лесном поясе горного Крыма // Там же. 1973. Т. 52, № 4. С. 821-829.

Рябухин А. С., Гильденков М. Ю. Материалы к фауне стафилинид подсемейства Oxytelinae (Coleoptera: Staphylinidae) Камчатки // Кавказский энтомологический бюллетень. 2018. Т. 14. Вып. 2. С. 147-150.

Bernhauer M. Entomologische Ergebnisse der schwedischen Kamtchatka-Expedition 1920-1922. 8. Staphylinidae // Arkiv för Zoologie. 1925. Bd. 18 B. No. 4. S. 1-2.

Campbell J. M. A revision of the genus Tachinus (Coleoptera: Staphylinidae) of North and Central America // Memoirs of the Entomological Society of Canada. 1973. No. 90.137 p.

Campbell J. M. A revision of the North American Omaliinae (Coleoptera: Staphylinidae). 2. The tribe Coryphiini // Memoirs of the Entomological Society of Canada. 1978. No. 106. P. 20-87.
Campbell J. M. A revision of the North American Omaliinae (Coleoptera: Staphylinidae). The genus Olophrum Erichson // The Canadian Entomologist. 1983. Vol. 115. P. 577-622.

Campbell J. M. A revision of the North American Omaliinae (Coleoptera: Staphylinidae). The genera Arpedium Erichson and Eucnecosum Reitter // Ibid. 1984. Vol. 116. P. 487-527.

Hatch M. H. The beetles of the Pacific Northwest. Part II: Staphyliniformia. Seattle : University of Washington Publication in Biology, 1957. Vol. 16. 384 p.

Herman L. H. Catalog of the Staphylinidae (Insecta: Coleoptera). 1785 to the end of the second Millennium. Parts I-VII. Bulletin of the American Museum of Natural History. New York, 2001. No. 265. 4218 p.

Ryabukhin A. S. A catalogue of rove beetles (Coleoptera: Staphylinidae exclusive of Aleocharinae) of the Northeast of Asia. Sofia; Moscow : Pensoft Publishers, 1999. $140 \mathrm{p}$.

Schülke M., Smetana A. Family Staphylinidae Latreille, 1802 // Catalogue of Palaearctic Coleoptera. Vol. 2/1. Hydrophiloidea-Staphylinoidea / eds. I. Löbl, D. Löbl. Leiden; Boston : Brill, 2015. P. 304-1134.

Shavrin A. $V$. A review of the genus Pycnoglypta Thomson, 1858 (Staphylinidae, Omaliinae, Omaliini) with notes on related taxa // Zootaxa. 2016. 4077 (1). P. 1-94.

\title{
MATERIALS ON THE FAUNA OF ROVE BEETLES (COLEOPTERA: STAPHYLINIDAE) OF THE KAMCHATKA TUNDRAS (Subfamilies OMALIINAE, PROTEININAE, PSELAPHINAE, TACHYPORINAE AND OXYTELINAE)
}

\author{
A. S. Ryabukhin \\ Institute of Biological Problems of the North, FEB RAS, Magadan
}

\begin{abstract}
Results of the study of the material, collected from various regions of Kamchatka, and summary of literature records are presented. 27 species of rove beetles from 16 genera, belonging to the subfamilies Omaliinae, Proteininae, Pselaphinae, Tachyporinae and Oxytelinae, are recorded for the fauna of the Kamchatka tundras. One taxon is identified only to the subfamily level (Pselaphinae gen. sp.). Three species of the genera Bryophacis Reitter, 1909, Mycetoporus Mannerheim, 1830, and Tachyporus Gravenhorst, 1802, all from the subfamily Tachyporinae, remain so far unidentified. Most species of rove beetles from the Kamchatka tundras are widespread in the Northern Palaearctic beyond. An annotated list of species has been compiled. Collecting localities are illustrated.
\end{abstract}

Keywords: Coleoptera, Staphylinidae, Kamchatka, fauna, tundras.

\section{REFERENCES}

Bernhauer, M., 1925, Entomologische Ergebnisse der Schwedischen Kamtchatka-Expedition 1920-1922, 8. Staphylinidae, Arkiv för Zoologie, 18, 4, 1-2.

Campbell, J. M., 1973, A Revision of the Genus Tachinus (Coleoptera: Staphylinidae) of North and Central
America, Memoirs of the Entomological Society of Canada, 90 .

Campbell, J. M., 1978, A Revision of the North American Omaliinae (Coleoptera: Staphylinidae), 2, The Tribe Coryphiini, Ibid., 106, 20-87. 
Campbell, J. M., 1983, A Revision of the North American Omaliinae (Coleoptera: Staphylinidae), The Genus Olophrum Erichson, The Canadian Entomologist, 115, 577-622.

Campbell, J. M., 1984, A Revision of the North American Omaliinae (Coleoptera: Staphylinidae), The Genera Arpedium Erichson and Eucnecosum Reitter, Ibid., 116, 487-527.

Gorodkov, K. B., 1984, Range Types of Insects in Tundra and Forests Zones of the European Part of the USSR, Areals of the Insects in the European Part of USSR, Atlas, Maps 179-221, Leningrad, Nauka, 3-20 [In Russian].

Hatch, M. H., 1957, The Beetles of the Pacific Northwest. Part II. Staphyliniformia, Seattle, University of Washington Publication in Biology, 16.

Herman, L. H., 2001, Catalog of the Staphylinidae (Insecta: Coleoptera), 1785 to the End of the Second Millennium, Parts I-VII, Bulletin of the American Museum of Natural History, New York, 265.

Lobkova, L. E.; Semenov, V. B., 2012, Staphylinides (Coleoptera, Staphylinidae) of the Kronotsky Reserve and Adjacent Territories of Kamchatka, Trudy Kronotskogo Gosudarstvennogo Prirodnogo Biosfernogo Zapovednika, Petropavlovsk-Kamchatsky, Kamchatpress, 2, 85-102 [In Russian].
Medvedev, S. I.; Sklyar, V. E., 1974, Beetles (Coleoptera) from Small Mammal Nests in the Donetsk Oblast, Entomological Review, 53, 3, 561-571 [In Russian].

Medvedev, S. I.; Sosnina, E. F., 1973, Beetles (Coleoptera) from the Nests of Muridae in the Forest Zone of the Mountainous Crimea, Ibid., 52, 4, 821-829 [In Russian].

Ryabukhin, A. S., 1999, A Catalogue of Rove Beetles (Coleoptera: Staphylinidae Exclusive of Aleocharinae) of the Northeast of Asia, Sofia; Moscow, Pensoft Publishers.

Ryabukhin, A. S.; Gildenkov, M. Yu., 2018, Materials to the Fauna of Rove Beetles Subfamily Oxytelinae (Coleoptera: Staphylinidae) of Kamchatka, Caucasian Entomological Bulletin, 14, 2, 147-150 [In Russian].

Schülke, M.; Smetana, A., 2015, Family Staphylinidae Latreille, 1802, Catalogue of Palaearctic Coleoptera. 2/1. Hydrophiloidea-Staphylinoidea, Eds. I. Löbl, D. Löbl, Leiden; Boston, Brill, 304-1134.

Shavrin A. V., 2016, A Review of the Genus Pycnoglypta Thomson, 1858 (Staphylinidae, Omaliinae, Omaliini) with Notes on Related Taxa, Zootaxa, 4077, 1, 1-94. 